\title{
Okonkwo and David's Fall: A Social- Psychological Analysis
}

\section{Manfath Jabin Haque*}

ISSN: 2311-8636 (Print)

ISSN: 2312-2021 (Online)

DOI prefix: 10.18034/ajhal

Licensed:

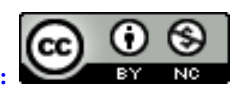

Source of Support: Nil

No Conflict of Interest: Declared

*Email for corresvondence:

Senior Lecturer, Department of English, Leading University, Surma Tower, Taltola, Sylhet, BANGLADESH

\section{ABSTRACT}

Almost in every sphere of life social factors shape human thoughts and behaviors. This writing attempts to survey the social-psychological grounds accountable for the 'fall' of the black protagonist Okonkwo in Chinua Achebe's Things Fall Apart and of the white protagonist David Lurie in J.M. Coetzee's Disgrace. My intention behind picking up two opposite personalities of different social background is not to show the 'comparative study' in the sense of the term but to focus on the working of human inner truth and its cyclic response to particular social factors and imposition. An individual's psychic crisis will arise if he has to receive any unexpected domination, interference or oppression. Likewise, the suppressed feelings of the 'oppressed' expose themselves if chance appears. Okonkwo, the Igbo hero of colonized Nigeria, cannot acclimate to the profound changes brought about by the British colonizers and is subjugated in the clash between two cultures and commits suicide to avoid humiliation from the colonizers. As a product of post-apartheid South Africa, David, along with his daughter, is severely assaulted by the newly powerful Blacks as a response of malevolence towards the former colonizers. With some exceptions, the parallel stories of the protagonists holding graceful positions in society and leading lives of free choice at the outset of the novels; going through the transitional period of wrongdoings resulted from individual faults and receiving punishment of facing harsh reality; and ultimately meeting their collapse as a consequence of the intrusive of external forces will ascertain that when panic and prejudice; hatred and resentment; lust for power and dominance come to the fore, effort at reconciliation is disregarded. If this state of affairs emerges, disintegration of human condition is unavoidable. 'Role reversal' may occur but 'long-term peace' is a concept like a mirage. Examination of psychological working and its relation to social condition can explore this state. This paper will endeavor to study the core causes regarding the inevitability of the fall of Okonkwo and David from social- psychological perspective.

Key Words: Post-apartheid, social-psychological, fall, inevitable, prejudice

\section{Presentation}

'Change' and 'replacement' are the enduring factors in every aspect of nature and human life. Literature paints the picture of life and society through the chosen colors of the concerned author. But certain inner truths of human psychology never change, and the 
portrait of these eternal truths is being presented in the different era with different exterior colors. Psychological involvement and social life entwine with each other. Okonkwo and David's irrevocability of failure hints this association. In Beginning Theory: An Introduction to Literary and Cultural Theory Peter Barry says: "Good literature is of timeless significance; it somehow transcends the limitation and peculiarities of the age it is written in, and thereby speaks to what is constant in human nature" (16).

The identities of Okonkwo and David are not any more distinctive with individual choice, freedom, rights, and beliefs; they are colonial subjects. British colonizers enter the village of Okonkwo and frustrate their social, political and religious matters; thus he directly becomes colonized. In post- apartheid South Africa, the Blacks are in power and David loses all privileges and control. His helplessness proclaims him as a colonial subject. They are dissimilar personalities from opposite social background. Nevertheless, the shifts and movements of their stories can be examined from three almost similar phases: First phase introduces the protagonists with their individual life style, second stage talks about their wrongdoings and exile, and the third segment drives to the climax and throws them to the pit of ignominy.

The story of Okonkwo, an Igbo hero, is set between1860-1890, the colonial period of Nigeria, in the fictional village Umuofia where unified people of integrated beliefs in custom and religion reside. Okonkwo is a self-made, well-respected member of the Igbo clan as portrayed in the starting of the novel: "Okonkwo was well known throughout the nine villages and even beyond. His fame rested on solid personal achievements" (Achebe1). He is stern and powerful, but his only fear is not to be like his father Onoka as he was a very idle man. Okonkwo is very industrious, brave, and masculine in every possible way. For valor and might in the war and wrestling, he is called, "Roaring Flame" (108). He is very firm in being successful and one of the authoritative men of the clan. He demonstrates his greatness by being wealthy, holding a high-ranked position in the community.

Disgrace shows the picture of mutual distrust among the races in post-apartheid South Africa where the power is shifted to the Black majority from the White minority. Apartheid consisted of numerous laws that allowed the governing white minority in South Africa to segregate, exploit, and terrorize the vast majority. In post- apartheid South Africa, David Lurie, the professor of Romantic poetry at the Technical University of Cape Town is a reckless consumer of life. He possesses the ambition to write a chamber opera about Byron's life in Italy, and a whimsical attitude towards sex. He is a middle-aged person and divorced scholar with dignity; he is run by his own law and maintains life from his own perspective. The first chapter portrays David being with a prostitute named Soraya. He spends a lavish life and rationalizes his lifestyle putting his long practiced and acquired depth of aestheticism and insight. Lurie is isolated and indifferent to the realization of the meaning of life: "He lives within his income, within his temperament, within his emotional means" (Coetzee 2). He believes his happiness depends on the frequent visit to prostitutes. In the age of fifty- two ninety minutes a week of a woman's company are enough to make him happy, "his needs turn out to be quite light, after all, light and fleeting, like those of a butterfly" (5).

Some characteristic weaknesses are also visible in Okonkwo. Okonkwo's extreme emotions and fear of being thought weak motivate him to take actions that are often unnecessary and ultimately destructive. The killing of Ikemefuna proves Okonkwo's blind loyalty to his culture and his ignorance to alternative values and interpretations. His sense of ownership is very apparent in the episode. Okonkwo treats his family members like his subjects and validates his cruel behavior against them since he believes: "No matter how prosperous a man was, if he was unable to rule his women and his children (and 
especially his women) he was not really a man. He was like the man in the song who had ten and one wives and not enough soup for his foo-foo" (37).

Nonetheless, Okonkwo is not a character without positive human emotions. He starts to like the ill-fated boy Ikemefuna for his spontaneous activity and strong influence in his (Okonkwo's) first son Nwoye. Okonkwo cannot trust and rely on Nwoye for his indolent and feminine nature. Of course, Okonkwo possess love and intimacy, "Perhaps down in his heart Okonkwo was not a cruel man. But his whole life was dominated by fear, the fear of failure and of weakness" (9). After the murder of Ikemefuna, who called him father, Okonkwo was disturbed: "Okonkwo did not taste any food for two days after the death of Ikemefuna. He drank palm wine from morning till night, and his eyes were red and fierce like the eyes of a rat when it was caught by the tail and dashed against the floor" (44). Following his daughter Ezinma's fate behind the priestess Chielo towards the cave ensures his tenderness and fatherly affection. But in the clash between maintaining the show of emotion and showing strength, he prefers the later.

In Disgrace, after his relation with Soraya, David becomes entangled with one of his students. Throughout the novel, David Lurie meets harsh criticism for his affair. He defends his action and tells Melanie, "a woman's beauty does not belong to her alone...she has a duty to share it" (16). Coetzee shows the problem of a modern man from different angles. David is a lonely man and loneliness deteriorates his feelings and he emerges into prioritizing self-passion. He teaches Byron and thinks himself as Byronic hero for whom sex has become a middle- aged crisis. David is indifferent to rational behavior about sex and it makes him unwilling to understand his wrongdoings. Melanie has no conscious willingness to allow him for physical relation. Neither he controls himself; nor does she resist. David is well aware that he is close to the fine line between undesired intercourse and rape. He acts as a 'servant of Eros' without any precautions that could save him. According to his perspective the relation is "not rape, not quite that, but undesired nevertheless" (25).

The strength of David's character is his honesty, straightforwardness, and firmness of will. He is harassed to admit his guilt and repent according to the law of the committee, but he does not repent and tries to uphold his belief. He says, "I am being asked to issue an apology about which I may not be sincere?" (58). Okonkwo is also an honest, strict follower of the laws of the clan, firm believer, and straightforward. But if he somehow breaks them either through the loss of temper as in the beating of his wife in the 'peace week' or inadvertently as in shooting the boy in funeral ceremony - he never questions the punishments brought upon him. He receives the due punishment without questioning.

After disgraceful dismissal from the University, David's period of self-exile starts. He escapes to his daughter's smallholdings and suffers from financial crisis. He engages himself with an unpaid job at an animal clinic run by Lucy's friend Bev Shaw. He just wants to go on as long as possible.

Okonkwo also meets his imposed exile of seven years by the clan as the punishment of accidentally killing a boy in Ezeudu's funeral: "It was the dead man's sixteen-year-old son, who with his brothers and half-brothers had been dancing the traditional farewell to their father. Okonkwo's gun had exploded and a piece of iron had pierced the boy's heart" (88). $\mathrm{He}$ is given seven years exile as punishment, because, "It was a crime against the earth goddess to kill a clansman, and a man who committed it must flee from the land. The crime was of two kinds, male and female. Okonkwo had committed the female, because it had been inadvertent" (88). 
In the transitional part of David's story after the resignation and during self-exile, the influence of his daughter and the natural rhythms of the farm promise to harmonize his discordant life. But, the country has already undergone a rapid and fundamental change. If the whites want to survive in South Africa, they have to be adaptable or even under the blacks' protection. Through depicting the character of Petrus, Coetzee has shown the condition of changed society and power. When being introduced to David, he says that he is '"the gardener and the dog-man'. He reflects for a moment. 'The dog-man,' he repeats, savouring the phrase" (64).It is interesting that Petrus already has four titles for his job. This perhaps shows that both Lucy and Petrus have different ideas for his profession. Lucy gives him the comparatively lavish title, 'Co-proprietor,' whereas Petrus ironically refers to himself as 'dog-man.' Here, it can be argued that Petrus is playing with Lurie's preoccupations with the black man's role. Later on in the novel he "is no longer, strictly speaking hired help. It is hard to say what Petrus is, strictly speaking" (116). When Coetzee makes it clear that in earlier times it would have been possible to have sorted out the problem with Petrus, it hints upon a wider scale of the whites having power over the blacks. Petrus has explored the changing political status by contrasting the constantly repeated 'old days' with the progression of this 'new world.' So Lurie's relationship with Petrus is central to relationship between the apartheid and the new post-apartheid South Africa.

Things have been changed a lot during Okonkwo's exile time in his mother's land Mbanta. Okonkwo manages to overcome his depression and prosper with the help of his kinsmen. In the meantime, we see the advent of the British missionaries. They start to arouse religious conflicts and to build trading stores:

"The colonizers believed that only their own Anglo-European culture was civilized, sophisticated, or, as postcolonial critics put it, metropolitan. Therefore, native peoples were defined as savage, backward, and undeveloped. Because their technology was more highly advanced, the colonizers believed that their whole culture was more highly advance, and they ignore or swept aside the religious, customs, and codes of behavior of the peoples they subjugated. So the colonizers saw themselves at the center of the peoples they subjugated. So the colonizers saw themselves at the center of the world; the colonized were at the margins" (Tyson 419).

These attitudes of the colonizers are very much noticeable in their dealings with the villagers. Okonkwo starts to develop hatred against their thoughts and activities. He feels like to chase the missionaries with whip.

The final climax of 'disgrace' results from the assault of David and his daughter Lucy. Lucy, unlike her father, accepts the post-apartheid situation. She seems to share the justifications of the black attackers of her house, and as soon as she discovers that she is pregnant as a result of the rape by them, she refuses to have an abortion. Apart from this, she agrees to offer her farm to Petrus and to become his third wife in name only in return for his protection:

"I don't believe you get that point, David. Petrus is not offering me a church wedding followed by a honeymoon on the Wild Coast. He is offering an alliance, a deal. I contribute the land, in return for which I am allowed to creep under his wing. Otherwise, he wants to remind me, I am without protection, I am fair game" (203).

Lucy can logically explain the attack and tries to cope with the situation. On the other hand, David cannot believe that the Blacks can assault them. 
Lucy's acceptance of the situation shows her compromise for survival. In the story, David does have a sense of powerlessness. In Things Fall Apart, Okonkwo's son Nwoye accepts the new religion (Christianity) and situation, as it gives an answer to "...a vague and persistent question that haunted his young soul--the question of the twins crying in the bush and the question of Ikemefuna who was killed" (104). He feels, "the words of the hymn were like the drops of frozen rain melting on the dry palate of the panting earth" (104). Okonkwo's heart cries in thought his other sons' following the abominable religion.

After coming back from exile, Okonkwo is not noticed as he has expected: "Umuofia had indeed changed during the seven years Okonkwo had been in exile. The church had come and led many astray. Not only the low-born and the outcast but sometimes a worthy man had joined it" (123). The indication of malpractices by the missionaries is clear from Obierika's description of the trial of land. The messenger demand extra money for the release of the six native prisoners. This indicates their so called 'civilization'. Okonkwo's war spirit rises and his close friend Obierika's reasoning cannot convince him in chapter twenty:

Our own men and our sons have joined the ranks of the stranger. They have joined his religion and they help to uphold his government. If we should try to drive out the white men in Umuofia we should find it easy. There are only two of them. But what of our own people who are following their way and have been given power? They would go to Umuru and bring the soldiers, and we would be like Abame (124).

In the similar vein, the sense of powerlessness works in David. The country has been transformed from an autocracy into a democracy. But, it does not mean that both races can live peacefully; brutal tyranny is replaced by brutal anarchy. When Lurie tries to confront Petrus about the rape, he seems to be scared of the consequences. He says, "I find it hard to believe the men who came here were strangers. I find it hard to believe they arrived out of nowhere, and did what they did" (118). This statement shows Lurie's contempt, but also a degree of panic and uncertainty of what he is saying. Coetzee shows Petrus to be comfortable and in complete control of the situation. He says "you are whipping yourself to a rage" and "yes, it was an outrage"(119). After the incident, Coetzee portrays Lurie in a pathetic way, the way "he sits on the toilet seat and tries to recover" (94), makes him seem helpless, even though he knows his daughter is in trouble. He then croaks feebly.

Individuals lead their life with self-confidence; sense of freedom and with sense of selfhonor. So if threat comes to their sense of freedom, they often rebel. This reflection is seen in Okonkwo's reaction to the intruders' interference in the affairs and beliefs of the natives. Okonkwo cannot compromise with the changes being brought by the colonizers. Therefore, when one of the masked spirits was unmasked by an over enthusiastic convert the elders of Umuofia burn the church. The conflict soars here. Six elders including Okonkwo are insulted like ordinary criminals and are treated like dogs by the District Commissioner. The climax of his suppressed resentment reaches to its height and by killing one of the messengers Okonkwo, for the time being, pacifies his spirit. Thus we see the clash between Okonkwo's personal pride and the actions forced on him by the external forces. His preconception of manliness, dignity, pride, love for the clan, uncompromising attitude lead him to break the custom of society purposefully and calculatedly by committing suicide. His sense of dignity and pride continues till the end and this makes him to choose living or dying rather than to submit to the wills of the intruders.

Attack on David's sense of individuality can be seen from the perspective found in Introduction to Psychology by Hillard, Earnest R., Richard C Atkinson, and Rita L Atkinson: 
"When circumstances block direct attack on the cause of frustration, aggression may be 'displaced'. Displaced aggression is an aggressive action against an innocent person or object rather than against the actual cause of frustration" (436). David becomes the scapegoat being the targeted object of 'displaced aggression' by the Blacks. His individuality is thwarted and he is hurled from the position of 'grace' to 'disgrace'. His metamorphosis is complete when he learns just to live giving up everything- dream, passion, and indifferent ways of life.

Rationalization of the cause of the downfall of Okonkwo and David comes respectively from Obierika and Lucy: Obierika says, "The white man is very clever. He came quietly and peaceably with his religion. We were amused at his foolishness and allowed him to stay. Now he has won our brothers, and our clan can no longer act like one. He has put a knife on the things that held us together and we have fallen apart" (125); about the revengeful assault of Lucy and his father by the blacks, Lucy says, "It was done with such personal hatred.

It may have seemed personal, but it wasn't. It came down from the ancestors"(156).

Though the degree of their fall varies, the 'fall' is complete - Okonkwo commits suicide after being treated like a dog, Obierika laments his death while talking to the District Commissioner: "That man was one of the greatest men in Umuofia. You drove him to kill himself and now he will be buried like a dog..."(147). David continues just living after coming down to the alignment of the status of a dog.

The authors of the two novels are concerned with the chaos unleashed by prejudice, racism and inequality. Deep contemplation searches the central point of their fall, because, "Practical problems of every sort fall within the domain of psychology" (Hilgard, Ernest R, et el, 563). Okonkwo is subjugated in the oppressive encounter with the colonizers; David succumbs to retribution as a colonial subject. Almost the whole world was under the British Empire and that is why Okonkwo's collapse is the outcome of colonialism. Apartheid is unique to South Africa and David Lurie's experience is not a common situation. The fall of David shows examples of loss of privilege, honor and power. He has no answer to give or no action to take against the violator, oppressor and thus succumbs to the encounter because "Now, it is colonialism that is regarded as psychopathological, a disease that distorts human relations and renders everyone within it 'sick"' (Loomba143).

People cherish latent desire to have and exercise unauthorized power and dominance over others. It creates frustration, conflict, and distrust; distrust evokes hostility; hostility leads to chaos; chaos is pacified somehow for a period- this is a cyclic process in the history of human existence irrespective of age, caste, class and religion. In case of Okonkwo, a black man is hastened to meet his individual and cultural doom by the white oppressors. Reversely, David, the white man receives the retort from the 'oppressed' resulted from suppressed malice. Real-life examples abound throughout the world. Where Compromise and compassion are indispensable for the healthy environment of living, there is hatred and avarice. The role reversal occurs; but not the hope of peace and toleration that is necessary for peace. Universal love, endurance and empathy which transcend race, religion and politics are absent, and so the fall of David and Okonkwo is inevitable: "Human nature is essentially unchanging. The same passions, emotions, and even situations are seen again and again throughout human history. It follows that continuity in literature is more important and significant than innovation" (Barry17). We find according to the sequence of events that where there 'things fall apart,' it results in the chaotic 'disgrace'; humiliation of human condition and values. 


\section{REFERENCES}

Achebe, Chinua. (2000), Things Fall Apart, Heinemann Educational Publishers, London.

Ashcroft, Bill, Gareth Griffiths, and Helen Tiffin, (2007) Post-Colonial Studies: The Key Concepts, Routledge, New York, NY.

Barry, Peter. (2002), Beginning Theory: An Introduction to Literary and Cultural Theory, Manchester University Press, Manchester.

Coetzee, J. M.,(1999), Disgrace, Vintage 2000, London.

Hillard, Earnest R., Richard C Atkinson, and Rita L Atkinson. Introduction to Psychology, Oxford \& IBH Publishing Co. PVT.LTD, New Delhi.

Loomba, Ania. (1998), Colonialism/ Postcolonialism. Rutledge, London.

Myers, David G. (2005), Social Psychology, MC Graw Hill, New York.

Tyson, Lois. (2006), Critical Theory Today: A User-Friendly Guide,Routledge,New York.

$--0-$ 


\section{Publish Online and Print Version Both}

ISSN Online: 2312-2021

\section{Why Open Access ???}

"In the traditional publishing model, readers have limited access to scientific papers; authors do not have copyright for their own papers, and cannot post their papers on their own websites, which presents a significant barrier to the sharing of knowledge, as well as being unfair to authors. Open access can overcome the drawbacks of the traditional publishing model and help scholars build on the findings of their colleagues without restriction" 